\title{
Quantitative (stereological) study of the effects of vasectomy on spermatogenesis in rhesus monkeys (Macaca mulatta)
}

\author{
B. Peng ${ }^{1}$, R. D. Zhang ${ }^{1}$, X. S. Dai ${ }^{1}$, X. Z. Deng², \\ Y. Wan ${ }^{3}$ and Z. W. Yang ${ }^{1 *}$ \\ ${ }^{1}$ Morphometric Research Laboratory, ${ }^{2}$ Department of Urological Surgery, and ${ }^{3}$ Operation Unit, \\ Affiliated Hospital, North Sichuan Medical College, Sichuan, People's Republic of China
}

\begin{abstract}
Vasectomy reversal by vasovasostomy after long-term vasectomy in men results in lower sperm counts and pregnancy rates compared with controls, and severe damage to spermatogenesis has been observed in some animal models such as mice. The primary aim of this study was to evaluate, using sophisticated stereological methods, whether vasectomy of 6 and 12 months in a non-human primate would lead to, among other morphometric changes, reduced numbers of germ cells in testes and spermatozoa in epididymides. Five normal adult male rhesus monkeys (Macaca mulatta) underwent bilateral vasectomy, with another three aged-matched normal monkeys not undergoing vasectomy. One testis together with the ipsilateral epididymis was removed from each animal at 6 months, and the other testis and epididymis, the prostate gland and seminal vesicles were removed at 12 months. Various morphometric data were obtained
\end{abstract}

\section{Introduction}

Vasectomy has been used widely for more than a century as a contraceptive method (especially since the late 1960s and early 1970s), occasionally for compulsory male sterilization for eugenic reasons or as a treatment for prevention of epididymitis in prostatic surgery or for rejuvenation (Drake et al., 1999). It has been estimated that up to 100 million men worldwide might have chosen vasectomy as a means of fertility control (Weiske, 2001).

Vasectomy can be surgically reversed, and a patency (return of spermatozoa to the ejaculate) rate of $86 \%$ (median; range: $77-100 \%$; mean \pm SEM: $87 \pm 3 \%$ ) and a pregnancy rate of $52 \%$ (median; range $28-82 \%$; mean $55 \pm 6 \%$ ) have been obtained after microsurgical vasovasostomy (Owen and Kapila, 1984; Lee, 1986; Silber, 1989; Belker et al., 1991; Chiang, 1996; Casella et al., 1997; Huang et al., 1997; Heidenreich et al., 2000). Failure to obtain patency was generally ascribed to stricture at the reversal site or secondary

*Address for correspondence: Morphometric Research Laboratory, North Sichuan Medical College, 234 Fujiang Road, Nanchong, Sichuan 637007, People's Republic of China

Email: zwyang@nc-public.sc.cninfo.net using stereological methods and an unbiased and efficient stereological tool, the optical disector, was used to estimate nuclear numbers of all types of spermatogenic cells in testes and spermatozoa in epididymides using methacrylate-embedded sections $25 \mu \mathrm{m}$ in thickness. As shown by a two-way repeated measures analysis of variance, vasectomy or hemicastration (removal of the organs at 6 months) had no significant effects on all quantitative parameters of stereology obtained from the testis, epididymis, prostate gland and seminal vesicle, except that (i) sperm granuloma was observed from three of five vasectomized animals both at 6 and 12 months, and (ii) hemicastration significantly reduced the diameter of the seminiferous tubules and increased the number of type A spermatogonia per testis. In conclusion, vasectomy in the non-human primate is a safe procedure in terms of effects on the structures of the reproductive organs. pressure-induced blockage of the epididymis (Silber, 1979, 1989; Matthews et al., 1997); repeat reversal procedures did increase patency to some extent (Belker et al., 1991; Chiang, 1996; Matthews et al., 1997; Donovan et al., 1998; Hernandez and Sabanegh, 1999; Fox, 2000). The pregnancy rate is always lower than the patency rate, which is usually thought to be the result of a decreased sperm count and quality of the semen (Lee, 1986; Huang et al., 1997; Yamamoto et al., 1997). For instance, among the subjects with successful vasectomy reversal, the sperm count $\left(35.4 \pm 0.5 \times 10^{6} \mathrm{ml}^{-1}\right)$ of men $(n=36)$ who impregnated their partners was significantly higher than that $\left(9.9 \pm 0.5 \times 10^{6} \mathrm{ml}^{-1}\right)$ of men $(n=19)$ who failed to do so (Huang et al., 1997). Vasovasostomy restored the fertility of seven of 14 vasectomized rabbits; the sperm counts of the two treated groups $\left(122 \pm 23 \times 10^{6} \mathrm{ml}^{-1}\right.$ versus $10 \pm 9 \times 10^{6} \mathrm{ml}^{-1}$ ) were significantly different and the sperm count of either treated group was significantly lower than that of the control group $\left(816 \pm 79 \times 10^{6} \mathrm{ml}^{-1}\right)$ (Wang et al., 1994). Azoospermia or decreased sperm count after vasectomy reversal are usually considered to be attributable to factors such as vas stenosis and epididymal obstruction unrelated to testicular damage. However, the possibility that vasectomy leads to spermatogenic lesions cannot be excluded on the basis of data available so far. 
The effects of vasectomy on spermatogenesis remain controversial (McDonald, 2000). Although many researchers failed to show any effects of vasectomy on spermatogenesis in humans (Silber, 1979), mice (Lohiya et al., 1976), monkeys (Hadley and Dym, 1983), rabbits (Lohiya et al., 1983) or rats (Lohiya et al., 1976; Flickingers et al., 1988), other studies did observe significant effects in dogs (Lohiya et al., 1975; Urry et al., 1976), guinea-pigs (Hutson et al., 1976), hamsters (Urena and Malavasi, 1980), humans (Gupta et al., 1975; Jenkins et al., 1979; Jarow et al., 1985, 1994), mice (Croft and Bartke, 1976; Barratt and Cohen, 1988; Singh and Chakravarty, 2000), monkeys (Chapman et al., 1978; Heidger et al., 1978; Tung and Alexander, 1980; Lohiya et al., 1987), musk shrew (Singh and Dominic, 1981), rabbits (Zhao et al., 1987; Liu et al., 1990; Wang et al., 1992), rams (Perera, 1978) or rats (Neaves, 1978; Dong et al., 1999; Whyte et al., 2000; Kubota et al., 2001). The time course of recovery of spermatogenesis after damage to spermatogenesis by vasectomy was not well demonstrated, but some recovery was reported in dogs (at 3-6 months after surgery: Lohiya et al., 1975; MacDougall et al., 1975; Urry et al., 1976), humans (at 2 years: Gupta et al., 1975), musk shrew (at 6 months: Singh and Dominic, 1981), rabbits (at 12 months: Liu et al., 1990, Wang et al., 1992) and rats (at 3 months: Whyte et al., 1998). Lue et al. (1997) showed a transient germ cell apoptosis 3 weeks after surgery in rats, with little or no detrimental effect on the morphological characteristics of spermatogenesis at 12 weeks after surgery. Besides, the pattern and extent of damage are far from clear.

The lack of uniformity in results may be attributable to factors such as species or individual variation, study design, postoperative complications, postoperative time interval and the methodology used to determine the spermatogenic status. In mice, for example, only a slight effect on spermatogenesis (with approximately 30\% decrease in number of spermatids at 6 months after vasectomy) was observed by Barratt and Cohen (1988), whereas a marked effect (with much depletion of germ cells 6-12 months after vasectomy) was reported by Singh and Chakravarty (2000). Aitken et al. (1999) reported that the percentage $(47 \pm 13 \%$ ) of atrophic seminiferous tubules in five testes from five unilaterally vasectomized (for 3 years) guinea-pigs was consistently higher than that $(6 \pm 2 \%)$ in the contralateral testis; however, owing to considerable individual variation in the sham-operated animals $(62 \%$ in one control animal versus $3.5-4.1 \%$ in the other three control animals), they were unable to reach a statistical conclusion with one-way analysis of variance that vasectomy led to the tubular atrophy. However, if only the vasectomized testis and the contralateral control testis are compared using the paired $t$ test, a significant difference is detected $(P<0.05)$. Heidger et al. (1978) and Perera (1978) investigated the effect over a long postoperative period in monkeys (1-66 weeks) and rams (3-45 months), but most testicular samples at each time point were obtained from only one or two animals.

Spermatogenesis involves several types of germ cell and it seems that the effects of vasectomy on spermatogenesis, if any, are not severe in most cases. Thus the methods used to express the spermatogenic activity are important. Previous studies described spermatogenesis either qualitatively (Gupta et al., 1975; Heidger et al., 1978; Tung and Alexander, 1980; Liu et al., 1990; Wang et al., 1992; Aitken et al., 1999, 2000; Singh and Chakravarty, 2000; Whyte et al., 2000), or with semiquantitative data such as (i) germ cell (two-dimensional nuclear profile) number per tubule (two-dimensional profile) (Zhao et al., 1987; McDonald and Scothorne, 1988), per tubule crosssection (two-dimensional profile) (Barratt and Cohen, 1988; Hirsch and Choi, 1990) or per Sertoli cell (two-dimensional nuclear profile) (Perera, 1978; Hadley and Dym, 1983); (ii) testicular biopsy score count (Flickinger et al., 1988); (iii) number of tubules with spermatids (Jarrow et al., 1994) or with fewer germ cells (Aitken et al., 1999); or (iv) the number (percentage) of haploid cells (spermatids and spermatozoa) as determined by flow cytometry (Dong et al., 1999; Shiraishi et al., 2001). The key and directly comparable parameters for the description of spermatogenesis are the numbers of all types of germ cell per unit volume of testis and per testis, yet there is a paucity of such data in vasectomized animals. Lue et al. (1997) obtained such numbers of germ cells (not including elongated spermatids) in the hamster testis vasectomized for up to 12 weeks using a standard stereological method based on nuclear profile counts and measurement of nuclear diameters, which is considered to be the best of previous morphometric methods used for quantitative description of spermatogenesis in vasectomized testis. But this method, strictly speaking, is still not unbiased. The best stereological tool for estimation of nuclear number is the optical disector, which is not only unbiased but also efficient compared with the physical disector. The optical disector was first used to estimate the number of germ cells in rats (Wreford, 1995), and we have used it to study spermatogenesis in monkeys (Zhengwei et al., 1997, 1998a; Wen and Yang, 2000), humans (Zhengwei et al., 1998b), rats (Wen and Yang, 2000; Wen et al., 2000) and rabbits (Zhang et al., 2002) under normal, gonadotrophin withdrawal or experimentally cryptorchid conditions.

It was reported that long-term vasectomy in langur monkeys (Presbytis entellus) (Lohiya et al., 1987) or men (Jakobsen et al., 1989) affected the secretory function of the prostate gland, thus decreasing the volume of ejaculated semen. The association between vasectomy and prostate cancer as suggested by some epidemiological studies (Weiske, 2001) remains controversial. There is also a paucity of morphometric data on the histological structures of the prostate gland and seminal vesicles after long-term vasectomy.

This study was therefore undertaken using a monkey model to re-evaluate the effects of vasectomy (at 6 and 12 months after surgery) on spermatogenesis by obtaining numbers of germ cells in the testes and spermatozoa in the epididymides using the optical disector, and on the 
structures of the prostate gland and seminal vesicles by obtaining morphometric data with other stereological methods.

\section{Materials and Methods}

\section{Animals and design}

Eight normal mature male rhesus monkeys (Macaca mulatta), aged $4-6(4.9 \pm 0.2)$ years, were included in the experiment. Bilateral vasectomy was performed in June on five randomly chosen animals, with a segment of vas deferens being excised and the cut ends being ligated with silk threads. (All excised parts, which were embedded in paraffin wax for preparation of sections, were histologically confirmed to be vas deferens.) No surgery was performed on the other three animals (control). Six months later, blood was obtained from a subcutaneous vein in one leg to perform blood counts using an automatic haematology analyser (Coulter, Germany) at The First People's Hospital of Yunnan Province in Kunming (Yunnan Province), and hemicastration was performed to remove ipsilateral testis and epididymis of one side (left or right, alternatively chosen) on each animal. After a further 6 months, the contralateral testis and epididymis, together with the prostate gland and seminal vesicles, were removed from all animals after perfusion via the heart with $700 \mathrm{ml}$ of phosphate-buffered saline and then 2 I of Zamboni's fixative.

An experienced surgeon performed all operations and anaesthesia was induced by intra-muscular injection of ketamine hydrochloride. The animals were obtained from the Kunming Institute of Animals Research attached to the Chinese Academy of Science, and were kept there in a large cage (approximately $45 \mathrm{~m}^{3}$ ) made of metal bars throughout the whole experiment. The study was approved by the Sichuan Committee of Family Planning and North Sichuan Medical College.

\section{Tissue processing}

On removal, testes and epididymides were further fixed by immersion in Bouin's fixative for about $48 \mathrm{~h}$. After fixation, testes and epididymides were immersed in $70 \%$ ethanol for 2 days and prostate glands and seminal vesicles for 9 months before further processing. Subsequently the whole organs were weighed using an electronic balance (HR-120, A\&D Company, Ltd., Tokyo; accuracy $0.1 \mathrm{mg}$ ) to calculate organ volumes.

Organs were first cut into parallel thick slices and two to four slices were sampled in a systematic random manner (evenly spaced). The thick slices were cut into thinner slices of about 1-2 mm in thickness, which were further cut into smaller blocks before sampling. Four (at 6 months) or five (at 12 months) testicular blocks per testis and four (at 6 months) or three (at 12 months) epididymal blocks per epididymis were systematically sampled for embedding in methacrylate resin (hydroxyethylmethacrylate, Heraeus Kulzer $\mathrm{GmbH}$, Wehrheim/Ts). Three blocks from each prostate gland and three from one (random) of the two seminal vesicles of the same animal were sampled for embedding in paraffin wax (JUNG-Histowax, Cambridge Instruments $\mathrm{GmbH}$, Nussloch). As could be seen from the cut surface of organ slices, except for the central area of most testes, all organs were fixed. Therefore testicular blocks were further immersion-fixed in Bouin's solution overnight before dehydration in ethanol and butanol. One methacrylateembedded section $25 \mu \mathrm{m}$ in thickness or one paraffinembedded section $5 \mu \mathrm{m}$ in thickness was cut from each block on a semi-automatic microtome (RM2145, Leica Instruments $\mathrm{GmbH}$, Nussloch). The average area of sections, as estimated by the simple conventional stereological point counting method, was about $29 \mathrm{~mm}^{2}$ for testis, $20 \mathrm{~mm}^{2}$ for epididymis and $10 \mathrm{~mm}^{2}$ for prostate gland and seminal vesicle.

Methacrylate-embedded testicular sections were stained with PAS (periodic acid-Schiff reagent) plus Harris haematoxylin, but epididymal sections were stained with haematoxylin only. Paraffin-embedded sections from the prostate gland and seminal vesicles were stained using a monoclonal antibody against smooth muscle $\alpha$-actin and counterstained with Harris haematoxylin. The monoclonal antibody was from Sigma (St Louis, MO). Diaminobenzidine (DAB) was used to develop the immunoreaction product and sections were mounted with a resin mounting medium as described by Zhengwei et al. (1998c), Huang et al. (2001) and Zhang et al. (2002).

\section{Stereology}

Number of cells. Germ cells were divided into groups of type A spermatogonia; type B spermatogonia; preleptotene, leptotene and zygotene primary spermatocytes; pachytene primary spermatocytes; secondary spermatocytes; early (steps 1-12) spermatids; and late elongated (steps 13-14) spermatids as described by Zhengwei et al. (1997) and Zhang et al. (2002). Pyknotic nuclei, the chromatin of which was dark and dense, were smaller and sometimes irregular in shape compared with their adjacent germ cell type and were grouped separately.

Numbers of germ cells and Sertoli cells per testis were estimated using the optical disector as described by Zhengwei et al. (1997, 1998a,b), Wen and Yang (2000), Wen et al. (2000) and Zhang et al. (2002). Briefly, a section was brought into focus using an oil immersion lens and observed on a computer screen at final magnification $\times 2677$. A set of four rectangular frames (each with area $17 \mu \mathrm{m} \times 22 \mu \mathrm{m}$ ) was superimposed on the image and fields were systematically sampled on each section with a motorized stage. In focusing down continually in the tissue section of $10 \mu \mathrm{m}$ in depth, the nuclei were counted as they came into the frames according to the disector counting rule. On each field all four frames were used for counting spermatogonia and secondary spermatocytes while only one (upper left) frame was used for other types of germ cell and Sertoli cells. The calculation of nuclear numerical density (number per volume of testis) was based on the 
number of nuclei counted and the volume of optical disectors used for the counting per testis. The total number of cells (number of nuclei being assumed to be equal to number of cells) per testis was calculated by multiplying the density with the testicular volume. An average of 466 fields per testis was sampled systematically and an average of 1530 nuclei was counted per testis.

The number of spermatozoa and other cells (round spermatids and other non-spermatozoa cells identified according to nuclear morphology) in the lumen of the epididymal tubules per epididymis was estimated in a similar way to that described by Wen and Yang (2000). Epididymal sections were observed at final magnification $\times 4417$ and a set of six frames (each with area $5 \mu \mathrm{m} \times 6 \mu \mathrm{m}$ ) was superimposed on the image. An average of 1290 optical disectors (each with volume $5 \mu \mathrm{m} \times 6 \mu \mathrm{m} \times 10 \mu \mathrm{m}$ ) was used for counting spermatozoa and 257 spermatozoa were counted per epididymis.

Volume per organ. The upper-left corner of a counting frame, intersection between the upper and left sides of the frame, was regarded as a test point. All four frames for testicular sections and only one upper left frame for epididymal sections were considered, that is four test points for testicular sections and one test point for epididymal sections were superimposed on each field. The numbers of test points hitting different structures such as the seminiferous tubules in testis and the epididymal tubules and sperm agglomerates (epididymal fluid with densely packed spermatozoa) in the epididymal tubules were recorded before nuclear counting on each field as described above.

Sections of the prostate gland and seminal vesicles were observed using a $\times 10$ objective lens at final magnification $\times$ 268. Twelve test points (see Huang et al., 2001) were superimposed on each field systematically sampled, and the numbers of test points hitting different structures were recorded (for example the tubuloalveolar glands and the epithelium and concretions in the alveoli, and the smooth muscle bundles in the fibromuscular stroma in the prostate gland, and the tubular glands sharply delineated by the muscular coat in the seminal vesicle). Averages of 335 and 102 test points were counted per epididymis and seminal vesicle, respectively.

The percentage volume (volume fraction) of a structure in an organ was estimated by the percentage of test points hitting the structure (a fraction of the total number of test points, per organ, superimposed on the whole section), and then the total volume of the structure in the organ was calculated by multiplying the percentage by the volume of the organ.

Tubule diameter and length. The same testicular and epididymal sections used for nuclear counting (described above) were observed again on screen using a $\times 10$ objective lens (final magnification $\times 268$ ). Round or elliptical seminiferous and epididymal tubule profiles (90 per testis and 59 per epididymis on average) were randomly sampled with a frame to measure their diameters, and then tubule lengths per organ were calculated from diameters and tubule volumes as described by Zhengwei et al. (1998a,b), Wen and Yang (2000), Wen et al. (2000) and Zhang et al. (2002).

\section{Statistical analysis}

Data in the text and tables are shown as mean \pm SEM. Two-way repeated measures (RM) analysis of variance (ANOVA) on one factor (general linear model) was used to detect whether vasectomy or hemicastration had an effect on testicular or epididymal structures, and whether there was interaction between vasectomy and hemicastration. When a significant effect $(P<0.05)$ was detected, all-pairwise multiple comparison procedures were performed using the Student-Newman-Keuls method. For the same purpose, the following tests, theoretically inappropriate in this case but more straightforward and easier to understand, were also performed as a double check: unpaired $t$ test was used to test the difference between vasectomized and control animals either at 6 or 12 months (to detect any significant effects of vasectomy), and paired $t$ test was used to test for any significant differences between 6 and 12 months either in the vasectomized or control animals (to detect any significant effects of hemicastration). Moreover, to check further for the reliability of the statistical inferences reached, the four or five testicular sections obtained from each testis were randomly divided into two subsets (each with two or three sections). Thus two stereological results (results 1 and 2) were obtained from the respective stereological measurements on the sections. Then the same statistical tests were repeated as described above using result 1 and result 2, respectively. Other statistical tests are indicted in the text where they are used. Significance of difference was set at $P<0.05$.

\section{Results}

At the beginning of experiment, the body weight of the eight animals was $6.9 \pm 0.6 \mathrm{~kg}$, which was significantly increased by $9.3 \pm 2.5 \%$ at 6 months (to $7.4 \pm 0.6 \mathrm{~kg}$ ) or by $12.2 \pm 4.7 \%$ at 12 months (to $7.6 \pm 0.6 \mathrm{~kg}$ ), without significant difference between the last two time points (one-way RM ANOVA in conjunction with the Student-NewmanKeuls method). There were no significant differences in age, body weights, haemoglobin concentration, erythrocyte count or leucocyte count between vasectomized and control animals (Table 1).

All sections were observed within a few days and no marked differences were seen in the histology of the testis, epididymis, prostate gland and seminal vesicle between vasectomized and control animals at 6 months (for testis and epididymis) or 12 months of experiment, except that a sperm granuloma was found on three epididymal sections, one from a vasectomized animal at 6 months and the other two from another two different vasectomized animals at 12 months (see Fig. 1). The granuloma on each of the three sections occupied about half of the section in area; since the 
Table 1. Age, body weight and blood counts in vasectomized $(n=5)$ and control $(n=3)$ adult rhesus monkeys

\begin{tabular}{lcc}
\hline & Vasectomized & Control \\
\hline Age (years) at start of study & $5.0 \pm 0.3$ & $4.7 \pm 0.3$ \\
Body weight $(\mathrm{kg})$ at start of study & $7.6 \pm 0.8$ & $5.7 \pm 0.4$ \\
Body weight $(\mathrm{kg})$ at 6 months after vasectomy & $8.1 \pm 0.8$ & $6.3 \pm 0.6$ \\
Body weight $(\mathrm{kg})$ at 12 months after vasectomy & $8.2 \pm 0.8$ & $6.6 \pm 0.9$ \\
Haemoglobin $\left(\mathrm{g} \mathrm{I}^{-1}\right)$ at 6 months after vasectomy & $154 \pm 3$ & $150 \pm 10$ \\
Erythrocyte count $\left(\left.10^{12}\right|^{-1}\right)$ at 6 months after vasectomy & $6.52 \pm 0.20$ & $6.11 \pm 0.39$ \\
Leucocyte count $\left(\left.10^{9}\right|^{-1}\right)$ at 6 months after vasectomy & $13.3 \pm 2.0$ & $11.6 \pm 1.0$ \\
\hline
\end{tabular}

Values are mean \pm SEM.

Bilateral vasectomy was performed at the beginning of the experiment. At 6 months, hemicastration was performed on both vasectomized and control animals. There was no significant difference between vasectomized and control animals in all parameters listed in this table (unpaired $t$ test).
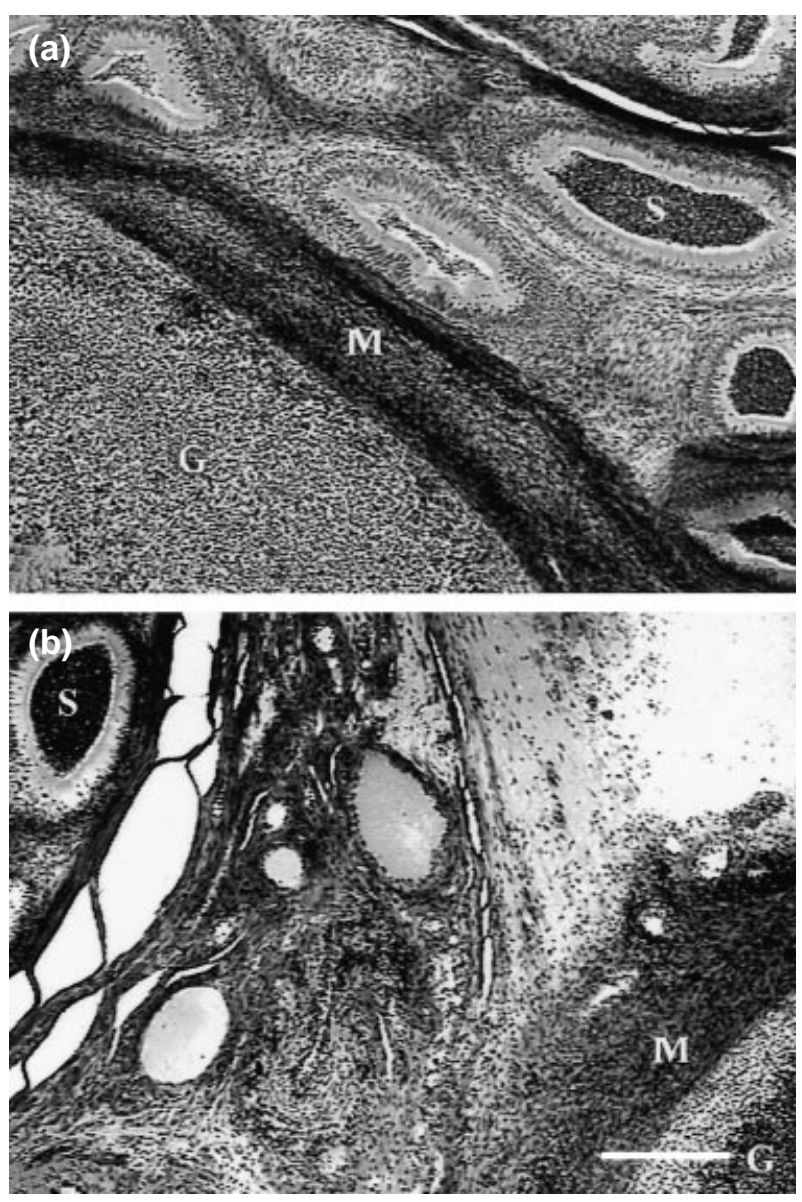

Fig. 1. Light micrographs of epididymal sections from two rhesus monkeys (Macaca mulatta) undergoing bilateral vasectomy, with one epididymis (together with the ipsilateral testis) being removed at (a) 12 months and the other at (b) 6 months after vasectomy. Micrographs were taken with a $\times 4$ objective lens on methacrylateembedded sections, $25 \mu \mathrm{m}$ in thickness, stained with haematoxylin. G: sperm granuloma densely packed with spermatozoa; M: the membrane (consisting mainly of dense connective tissue) of the sperm granuloma; S: sperm agglomerate (densely packed with spermatozoa) in the epididymal tubule. Scale bar represents $300 \mu \mathrm{m}$. total number of epididymal sections from vasectomized animals was 35 , the granuloma constituted about $4 \%$ of the total section area and therefore about $4 \%$ of the total epididymal volume according to the stereological principle.

As indicated by a two-way RM ANOVA, hemicastration had a significant effect on the number of type A spermatogonia per unit volume of testis and per testis and the diameter of the seminiferous tubules (Table 2 and Fig. 2). The same statistical inferences were also reached when the analyses were performed using the two subsets of data obtained by dividing the testicular sections into two subsets as described. Six months after hemicastration, the number of type A spermatogonia per testis increased significantly by $77 \pm 24 \%$ (range $1-191 \%, n=8$ ), and the number per unit volume increased significantly by $176 \pm 56 \% \quad(n=8$, decreased by $2 \%$ in one animal and increased by $8-455 \%$ in the other seven animals), whereas the diameter of the seminiferous tubules decreased significantly by $17 \pm 6 \%$ ( $n=8$, the diameter increased by $12 \%$ in one animal and decreased by $9-44 \%$ in the other seven animals). After hemicastration the volumes of the remaining testis and epididymis and the numbers of spermatocytes and spermatids per remaining testis and spermatozoa per remaining epididymis appeared to have become smaller but the differences were not significant.

The two-way RM ANOVA revealed that vasectomy did not have any significant effects on all quantitative data obtained in the present study (Table 2), after allowing for effects of hemicastration (described above), except the numerical densities $\left(\times 10^{6} \mathrm{~cm}^{-3}\right)$ of type $A$ spermatogonia, which, in the vasectomized and control groups, were $18.8 \pm 3.6$ and $16.2 \pm 2.2$ at 6 months and $50.6 \pm 4.9$ and $30.1 \pm 7.4$ at 12 months, respectively. There was no interaction between vasectomy and hemicastration. The statistical conclusions using the two subsets of data (obtained by dividing the testicular sections into two subsets as described) for comparisons were the same for all quantitative parameters obtained in this study except that the significance of vasectomy on the numerical density of type A spermatogonia was detected using one subset of data only. 
Table 2. Quantitative data of the main testicular and epididymal structures in vasectomized $(n=5)$ and control $(n=3)$ rhesus monkeys

\begin{tabular}{|c|c|c|c|c|}
\hline \multirow[b]{2}{*}{ Parameters } & \multicolumn{2}{|c|}{ Six months after vasectomy } & \multicolumn{2}{|c|}{ Twelve months after vasectomy } \\
\hline & Vasectomized & Control & Vasectomized & Control \\
\hline \multicolumn{5}{|l|}{ Volume $\left(\mathrm{cm}^{3}\right)$} \\
\hline Testis & $18.4 \pm 3.0$ & $16.8 \pm 4.8$ & $11.0 \pm 1.3$ & $13.9 \pm 2.1$ \\
\hline Epididymis & $4.31 \pm 0.60$ & $3.24 \pm 0.55$ & $3.54 \pm 0.53$ & $2.85 \pm 0.33$ \\
\hline \multicolumn{5}{|l|}{ Volume per organ $\left(\mathrm{cm}^{3}\right)$} \\
\hline Seminiferous tubules & $14.6 \pm 2.2$ & $13.5 \pm 3.9$ & $8.9 \pm 1.3$ & $11.6 \pm 2.0$ \\
\hline Epididymal tubules & $1.90 \pm 0.48$ & $1.52 \pm 0.33$ & $1.46 \pm 0.40$ & $1.22 \pm 0.28$ \\
\hline \multicolumn{5}{|l|}{ Diameter $(\mu \mathrm{m})$} \\
\hline Seminiferous tubules* & $177 \pm 8$ & $160 \pm 15$ & $142 \pm 6^{\mathrm{a}}$ & $154 \pm 2$ \\
\hline Epididymal tubules & $277 \pm 11$ & $287 \pm 26$ & $272 \pm 24$ & $252 \pm 23$ \\
\hline \multicolumn{5}{|l|}{ Length per organ (m) } \\
\hline Seminiferous tubules & $573 \pm 38$ & $620 \pm 85$ & $539 \pm 45$ & $610 \pm 99$ \\
\hline Epididymal tubules & $29.6 \pm 6.3$ & $21.2 \pm 2.2$ & $21.6 \pm 4.4$ & $22.2 \pm 1.8$ \\
\hline \multicolumn{5}{|c|}{ Number of cells $\left(\times 10^{6}\right.$ per organ) } \\
\hline Type A spermatogonia* & $312 \pm 28$ & $293 \pm 114$ & $542 \pm 59^{a}$ & $410 \pm 117$ \\
\hline Type B spermatogonia & $292 \pm 82$ & $419 \pm 148$ & $308 \pm 75$ & $173 \pm 58$ \\
\hline $\mathrm{Pl}-\mathrm{Z}$ & $508 \pm 193$ & $750 \pm 274$ & $372 \pm 101$ & $343 \pm 119$ \\
\hline$P$ & $1460 \pm 328$ & $1634 \pm 557$ & $1084 \pm 246$ & $1397 \pm 236$ \\
\hline Secondary spermatocytes & $100 \pm 24$ & $110 \pm 34$ & $86 \pm 27$ & $65 \pm 21$ \\
\hline R-E & $6250 \pm 1444$ & $5289 \pm 2772$ & $3427 \pm 818$ & $4324 \pm 1064$ \\
\hline $\mathrm{L}$ & $2932 \pm 526$ & $2688 \pm 1225$ & $1160 \pm 286$ & $1896 \pm 911$ \\
\hline Sertoli cells (testis) & $1144 \pm 89$ & $1391 \pm 136$ & $1252 \pm 159$ & $1391 \pm 169$ \\
\hline Spermatozoa (epididymis) & $3374 \pm 1662$ & $3504 \pm 1550$ & $2747 \pm 1131$ & $1278 \pm 993$ \\
\hline
\end{tabular}

Values are mean \pm SEM.

Ipsilateral testis and epididymis were first removed from bilaterally vasectomized and age-matched control (not undergoing vasectomy) adult animals at 6 months after surgery and then the contralateral organs were removed at 12 months ( 6 months after hemicastration).

L: late elongated spermatids; P: pachytene primary spermatocytes; PI-Z: preleptotene, leptotene and zygotene primary spermatocytes; R-E: early spermatids (round and elongating spermatids).

*Hemicastration but not vasectomy had a significant effect and there was no significant interaction between hemicastration and vasectomy (two-way repeated measure ANOVA).

aSignificantly different from the vasectomized in the ' 6 month' group (paired $t$ test).

Only 1-4 pyknotic nuclei were counted per testis; the numbers per testis in the vasectomized and control groups were $8 \pm 2 \times 10^{6}$ and $7 \pm 2 \times 10^{6}$ at 6 months and $2 \pm 1 \times 10^{6}$ and $4 \pm 1 \times 10^{6}$ at 12 months, respectively. The numbers of round spermatids and other non-sperm cells in the epididymal lumen were very small compared with the numbers of spermatozoa (Table 2). Those nonsperm cells were counted (by the optical disectors used) in half of the epididymides (that is, the numbers counted from the other organs were 0 ). The numbers of round spermatids per epididymis in the vasectomized and control groups were $3 \pm 2 \times 10^{6}$ and $5 \pm 5 \times 10^{6}$ at 6 months, and $22 \pm 11 \times 10^{6}$ and $2 \pm 2 \times 10^{6}$ at 12 months, respectively; those of other non-sperm cells were $8 \pm 5 \times 10^{6}$ and $5 \pm 4 \times 10^{6}$ at 6 months, and $148 \pm 144 \times 10^{6}$ (the number in one animal was extremely high: 726) and $2 \pm 2 \times 10^{6}$ at 12 months, respectively. Owing to the small number of nuclei counted and the large individual variation in the number of cells, statistical tests were not performed.

Compared with controls, the prostate gland and seminal vesicles from vasectomized animals were unchanged in all the quantitative parameters obtained in this study (Table 3).

\section{Discussion}

This study, the first to evaluate the spermatogenic effects of vasectomy using the optical disector, demonstrated that vasectomy in the rhesus monkey for 6 or 12 months did not significantly damage spermatogenesis or reduce the number of spermatozoa in the epididymis, although sperm granuloma was formed in the epididymis. Thus, vasectomy is a safe procedure in terms of spermatogenesis, and recovery of sperm concentration following a vasectomy reversal would depend mainly on the quality of the surgery itself in terms of vasal re-canalization.

Semen consists predominantly of secretions from the prostate gland and seminal vesicles. The present study demonstrated that the main histological structures in these organs were unaffected, indicating indirectly that the volume of semen was probably unchanged following vasectomy. The study also showed that prostate cancer was not induced after one year of vasectomy in this model. The conclusion may therefore be that short-term (up to 1 year) vasectomy would not considerably affect the morphology or function of the prostate gland and seminal vesicles. 

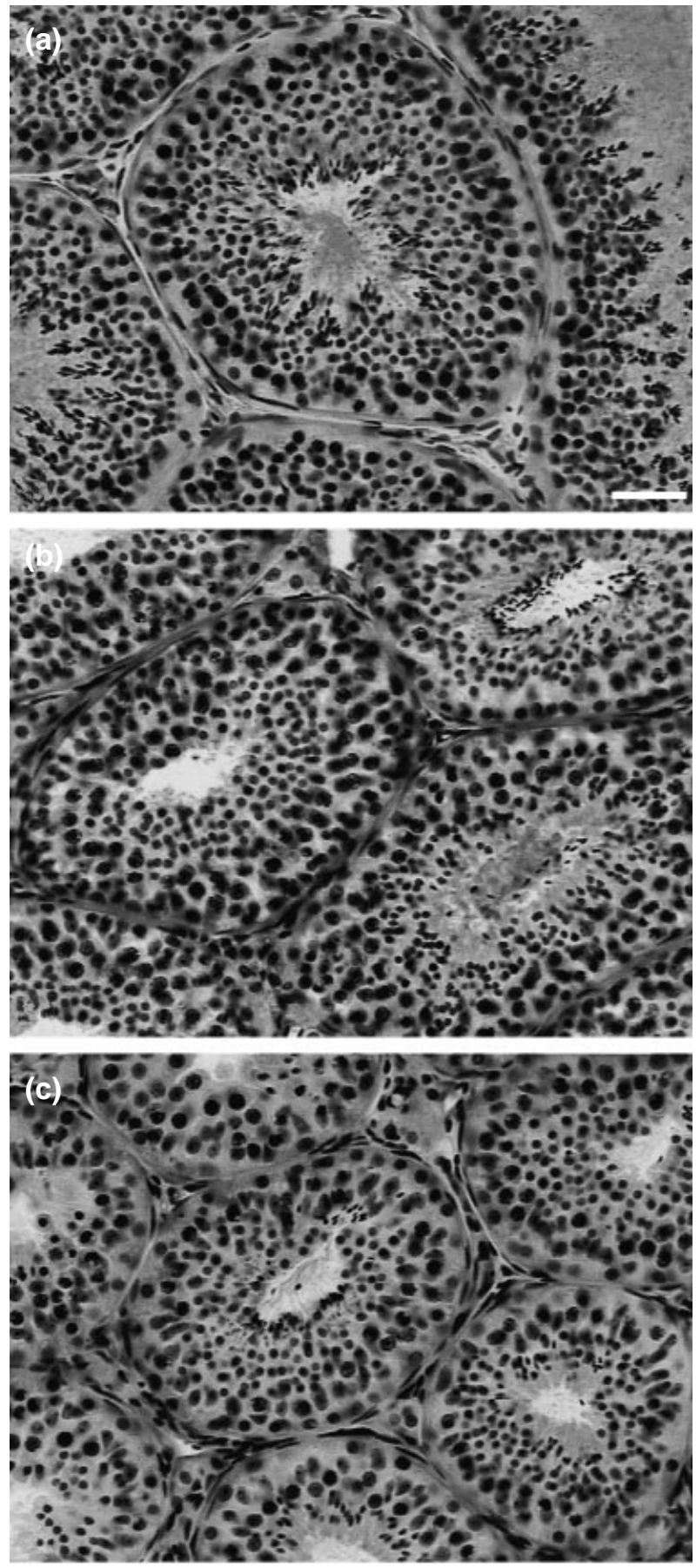

Fig. 2. Light micrographs of testicular sections of rhesus monkeys (Macaca mulatta). (a) and (b) were from the same animal that underwent bilateral vasectomy, with one testis (together with the ipsilateral epididymis) being removed at (a) 6 months and (b) 12 months. (c) Testis, removed at one year, of another rhesus monkey that did not undergo vasectomy but was hemicastrated 6 months after the start of the experiment. Micrographs were taken with a $\times 20$ objective lens on methacrylate-embedded sections, $25 \mu \mathrm{m}$ in thickness, stained with periodic acid-Schiff (PAS) plus haematoxylin. Scale bar represents $40 \mu \mathrm{m}$.
The present study was not originally designed to study the effects of hemicastration on spermatogenesis, but the results did show some effects. Ramaswamy et al. (2000) reported that at 44 days after hemicastration in rhesus monkeys the mass (average $37.3 \mathrm{~g}$ ) of the remaining testis significantly increased by about $36 \%$ compared with that (average $27.4 \mathrm{~g}$ ) of the testis removed at hemicastration. In contrast, a trend of decrease rather than increase was found in the current study: the ratio between the volumes of the remaining and hemicastrated testes of the same animals was $0.76 \pm 0.11(n=8$, range $0.40-1.12$, five individual ratios $<1$; paired $t$ test, $P=0.053)$. It remains to be clarified whether the discrepancy was due to a different time interval (6 months in the current study) after hemicastration. Hochereau-de Reviers et al. (1976) too reported an increase (by $40 \%$ ) in testicular size after hemicastration (for 4-6 months) in adult rams. However, most studies showed that hemicastration in adult patients or animals did not induce a change in testicular size, for example in men (Ferreira et al., 1991; Lin et al., 1998), monkeys (Zhengwei et al., 1998a) and rats (Howland and Skinner, 1975; Frankel and Wright, 1982; Bergh and Damber, 1991; Brown and Chakraborty, 1991). Compensatory testicular hypertrophy generally occurred when hemicastration was induced in prepubertal or neonatal animals, for example in boars (Kosco et al., 1987), bulls (Schanbacher et al., 1987), lambs (Waites et al., 1983), rams (Walton et al., 1980; Jenkins and Waites, 1983) and rats (Cunningham et al., 1978; Putra and Blackshaw, 1982; Orth et al., 1984; Ultee-van Gessel et al., 1985; Brown and Chakraborty, 1991; Simorangkir et al., 1995).

After obtaining the number of nuclei per testis indirectly from nuclear counts per tubule cross-section (essentially a nuclear profile counting method) in combination with the length of the seminiferous tubules per testis (although the result may have been affected by bias resulting from the counting method and non-systematic random sampling of cells on sections), Ramaswamy et al. (2000) reported that 44 days after hemicastration in monkeys the numbers of spermatogenic cells such as spermatocytes and spermatids increased with increase of testicular sizes, whereas the numbers of Sertoli cells and type A spermatogonia did not increase. Similar changes were observed in the developing rat (aged 1-70 days), in which the numbers of Sertoli cells and spermatogonia per testis remained stable from day 15 to day 30, respectively, whereas there was a trend of continual increase in testicular sizes and numbers of spermatocytes and round spermatids per testis (Wang et al., 1989; Yang et al., 1990). In addition, increases in the testicular size and the number of spermatids (but not the number of spermatogonia) were also reported in adult rabbits that were 7 weeks older (Zhang et al., 2002).

The present study demonstrated that hemicastration resulted in a significant reduction in the diameter of the seminiferous tubules. The number of late elongated spermatids per testis also appeared to be smaller: the ratio between the numbers (per testis) in the remaining and hemicastrated testes of the same animal was $0.66 \pm 0.19(n=8$, 
Table 3. Volumes $\left(\mathrm{cm}^{3}\right)$ of the prostate gland and seminal vesicle (average of both sides), and volumes of their main structures per organ in vasectomized $(n=5)$ and control $(n=3)$ adult rhesus monkeys

\begin{tabular}{lcc}
\hline & Vasectomized & Control \\
\hline Prostate gland & & \\
$\quad$ Organ & $2.01 \pm 0.27$ & $2.03 \pm 0.29$ \\
$\quad$ Glandular epithelium & $0.404 \pm 0.063$ & $0.385 \pm 0.031$ \\
$\quad$ Glandular cavity & $0.247 \pm 0.045$ & $0.369 \pm 0.096$ \\
$\quad$ Concretion in the glandular cavity & $0.071 \pm 0.022$ & $0.028 \pm 0.006$ \\
$\quad$ Smooth muscle bundles in the stroma & $0.675 \pm 0.120$ & $0.561 \pm 0.101$ \\
Seminal vesicle & & \\
$\quad$ Organ & $4.45 \pm 0.63$ & $4.09 \pm 0.18$ \\
$\quad$ Tubular gland & $3.03 \pm 0.57$ & $3.12 \pm 0.16$ \\
\hline
\end{tabular}

Values are mean \pm SEM.

Ipsilateral testis and epididymis were removed from bilaterally vasectomized and age-matched control (not undergoing vasectomy) animals 6 months after the start of the experiment, and the prostate gland and the bilateral seminal vesicles were removed at 12 months (6 months after hemicastration). There was no significant difference between vasectomized and control animals in any of the parameters (unpaired $t$ test).

range $0.20-1.50$, six individual ratios $<1$; paired $t$ test, $P=0.057$ ). In accord, the ratio between the numbers (per epididymis) of spermatozoa in the remaining epididymis and the epididymis removed at hemicastration was $0.65 \pm 0.18(n=8$, range $0.03-1.65$, six individual ratios $<1$; paired $t$ test, $P=0.112$ ). Thus, it is possible that the number of elongated spermatids per remaining testis, or spermatozoa per remaining epididymis would be significantly reduced in the longer term (more than 6 months after hemicastration). This speculation provides an explanation for the clinical reports that sperm counts significantly decreased after long-term hemicastration due to testicular trauma in men (Ferreira et al., 1991; Lin et al., 1998).

As shown in the present study, hemicastration led to an increase in the number of type A spermatogonia per testis. This finding may be the result of increased FSH concentrations. Although serum FSH concentrations were not measured here, other studies did consistently show that hemicastration brought about sustained high concentrations of FSH after long-term hemicastration in adult men (Lin et al., 1998) and adult monkeys (Ramaswamy et al., 2000). In addition, FSH treatment for 28 days in normal adult cynomolgus monkeys (Macaca fascicularis) significantly increased (by 100\%) the numbers (probably nuclear profiles per Sertoli cell nuclear profile) of type A pale spermatogonia, type $\mathrm{B}_{4}$ spermatogonia, PI-Z spermatocytes or round spermatids (van Alphen et al., 1988). The finding of the present study that an increased number of type A spermatogonia in hemicastrated monkeys was not associated with increased numbers of advanced spermatogenic cells indicates that FSH is not the only factor regulating spermatogenesis (Zhengwei et al., 1998a; McLachlan, 2000), and the exact mechanism needs to be studied further.

The authors are grateful to researchers Ji-Qiang Zhang and De-Ying Chen from the Third Military Medical University
(Chongqing) and Li-Yan Li and Lang Li from the Kunming Medical College (Yunnan) for their help in the perfusion fixation, and to pathologist Ting-Bi $\mathrm{Yu}$ (North Sichuan Medical College) for examining the prostatic sections. This study was supported by grants from the Sichuan Committee of Family Planning, the Sichuan Youth Foundation of Science and Technology and the Chinese Ministry of Education.

\section{References}

Aitken H, Kumarakuru S, Orr R, Reid O, Bennett NK and McDonald SW (1999) Effect of long-term vasectomy on seminiferous tubules in the guinea pig Clinical Anatomy 12 250-263

Aitken H, Kumarakuru S, Reid O, Milne EW, Bennett NK and McDonald SW (2000) Degenerated tubules in the guinea pig testis after long-term vasectomy or sham operation Clinical Anatomy 13 6-10

Barratt CL and Cohen J (1988) Quantitative effects of short- and long-term vasectomy on mouse spermatogenesis and sperm transport Contraception 37 415-424

Belker AM, Thomas AJ, Jr, Fuchs EF, Konnak JW and Sharlip ID (1991) Results of 1,469 microsurgical vasectomy reversals by the Vasovasostomy Study Group Journal of Urology 145 505-511

Bergh A and Damber JE (1991) Does unilateral orchidectomy influence blood flow, microcirculation and vascular morphology in the remaining testis International Journal of Andrology 14 453-460

Brown JL and Chakraborty PK (1991) Comparison of compensatory pituitary and testicular responses to hemicastration between prepubertal and mature rats Journal of Andrology 12 119-125

Casella R, Luscher U, Gasser TC, de Roche R and Leibundgut B (1997) Results of microsurgical reconstruction after vasectomy Schweiz Rundsch Med Prax [Germany] 86 933-936

Chapman ES, Heidger PM, Jr, Harrison RM, Roberts JA, Domingue GJ and Schlegel JU (1978) Vasectomy in rhesus monkeys. IV. Electron microscopic studies of the seminiferous epithelium Anatomical Record $19241-53$

Chiang HS (1996) Clinical study of vasectomy reversal: results of 60 singlesurgeon cases in Taiwan Journal of the Formosan Medical Association $95866-869$

Croft BT and Bartke A (1976) Quantitative study of spermatogenesis in vasectomized mice International Journal of Fertility 21 61-64

Cunningham GR, Tindall DJ, Huckins C and Means AR (1978) Mechanisms for the testicular hypertrophy which follows hemicastration Endocrinology 102 16-23 
Dong Q, Li H, Yang Y, Huang M and Lei S (1999) The effect of vasectomy on spermatogenesis and proliferation of rat spermatogenic cell Journal of West China University of Medical Sciences (China) 30 417-419

Donovan JF, Jr, DiBaise M, Sparks AE, Kessler J and Sandlow JI (1998) Comparison of microscopic epididymal sperm aspiration and intracytoplasmic sperm injection/in-vitro fertilization with repeat microscopic reconstruction following vasectomy: is second attempt vas reversal worth the effort Human Reproduction 13 387-393

Drake MJ, Mills IW and Cranston D (1999) On the chequered history of vasectomy BJU International 84 475-481

Ferreira U, Netto NR, Jr, Esteves SC, Rivero MA and Schirren C (1991) Comparative study of the fertility potential of men with only one testis Scandinavian Journal of Urology and Nephrology 25 255-259

Flickinger CJ, Howards SS, Carey PO, Spell DR, Kendrick SJ, Caloras D, Gallien TN and Herr JC (1988) Testicular alterations are linked to the presence of elevated antisperm antibodies in Sprague-Dawley rats after vasectomy and vasovasostomy Journal of Urology 140 627-631

Fox M (2000) Failed vasectomy reversal: is a further attempt using microsurgery worthwhile? BJU International 86 474-478

Frankel Al and Wright WW (1982) The hemicastrated rat: definition of a model for the study of the regulation of testicular steroidogenesis Journal of Endocrinology 92 213-223

Gupta AS, Kothari LK and Bapna RB (1975) Surgical sterilization by vasectomy and its effects on the structure and function of the testis in man British Journal of Surgery 62 59-63

Hadley MA and Dym M (1983) Spermatogenesis in the vasectomized monkey: quantitative analysis Anatomical Record 205 381-386

Heidenreich A, Altmann P and Engelmann UH (2000) Microsurgical vasovasostomy versus microsurgical epididymal sperm aspiration/ testicular extraction of sperm combined with intracytoplasmic sperm injection. A cost-benefit analysis European Urology 37 609-614

Heidger PM, Jr, Roberts JA, Chapman ES, Domingue GJ, Harrison RM and Schlegel JU (1978) Vasectomy in rhesus monkeys. III. Light microscopic studies of testicular morphology Urology 11 148-152

Hernandez J and Sabanegh ES (1999) Repeat vasectomy reversal after initial failure: overall results and predictors for success Journal of Urology 161 1153-1156

Hirsch IH and Choi H (1990) Quantitative testicular biopsy in congenital and acquired genital obstruction Journal of Urology 143 311-312

Hochereau-de Reviers MT, Loir M and Pelletier J (1976) Seasonal variations in the response of the testis and $\mathrm{LH}$ levels to hemicastration of adult rams Journal of Reproduction and Fertility 46 203-209

Howland BE and Skinner KR (1975) Changes in gonadotropin secretion following complete or hemicastration in the adult rat Hormone Research $671-77$

Huang A, Zhang R and Yang Z (2001) Quantitative (stereological) study of placental structures in women with pregnancy iron-deficiency anemia European Journal of Obstetrics \& Gynecology and Reproductive Biology 97 59-64.

Huang MK, Wu XQ, Fu CS, An Q, Zou P, Gao XP and Huang Q (1997) A study of multiple factors affecting human repregnancy after microsurgical vasovasostomy Reproduction and Contraception (China) 17 359-364

Hutson JC, Gardner PJ and Lacy SS (1976) Changes in testis of guinea pig after vasectomy Urology 7 287-291

Jakobsen H, Rui H, Thomassen Y, Hald T and Purvis K (1989) Polyamines and other accessory sex gland secretions in human seminal plasma 8 years after vasectomy Journal of Reproduction and Fertility $\mathbf{8 7} 39-45$

Jarow JP, Budin RE, Dym M, Zirkin BR, Noren S and Marshall FF (1985) Quantitative pathologic changes in the human testis after vasectomy. A controlled study New England Journal of Medicine 313 1252-1256

Jarow JP, Goluboff ET, Chang TS and Marshall FF (1994) Relationship between antisperm antibodies and testicular histologic changes in humans after vasectomy Urology 43 521-524

Jenkins IL, Muir VY, Blacklock NJ, Turk JL and Hanley HG (1979) Consequences of vasectomy: an immunological and histological study related to subsequent fertility British Journal of Urology 51 406-410

Jenkins $\mathbf{N}$ and Waites GM (1983) Effects of hemicastration at various ages and of oestradiol-17 beta on plasma concentrations of gonadotrophins and androgens, testicular growth and interstitial cell responses in prepubertal lambs Journal of Reproduction and Fertility 68 325-334

Kosco MS, Bolt DJ, Wheaton JE, Loseth KJ and Crabo BG (1987) Endocrine responses in relation to compensatory testicular growth after neonatal hemicastration in boars Biology of Reproduction 36 1177-1185

Kubota Y, Sasaki S, Kubota H, Tatsura H and Kohri K (2001) A study on the mechanism of the spermatogenic damage after vasectomy in rats Nippon Hinyokika Gakkai Zasshi (Japan) 92 13-22

Lee HY (1986) A 20-year experience with vasovasostomy Journal of Urology 136 413-415

Lin WW, Kim ED, Quesada ET, Lipshultz LI and Coburn M (1998) Unilateral testicular injury from external trauma: evaluation of semen quality and endocrine parameters Journal of Urology 159 841-843

Liu FX, Zhao XJ, Wang ZS, Lin H, Zhao D, Zhao YL, Hu JD and Sun YQ (1990) Observation of histological changes of testes in vasectomized rabbits with PAP staining Journal of Norman Bethune University of Medical Sciences (China) 16 37-39

Lohiya NK, Dixit VP and Arya M (1975) Biochemical and histological changes in testes and epididymis of dog after vasectomy Acta Europaea Fertilitatis 6 361-369

Lohiya NK, Dixit VP and Arya M (1976) Long-term effects of vasectomy on the pituitary-gonadal system of rat and mouse Endokrinologie $\mathbf{6 7}$ 152-159

Lohiya NK, Mathur N, Tiwari SN and Shipstone AC (1983) Ultrastructural changes in rabbit testis and epididymis following vasectomy: a long term study Acta Europaea Fertilitatis 14 141-146

Lohiya NK, Tiwary SN, Ansari AS and Watts N (1987) Long-term vasectomy effects on testis and accessory sex organ function in langur monkey Acta Europaea Fertilitatis 18 207-211

Lue Y, Hikim AP, Wang C, Bonavera JJ, Baravarian S, Leung A and Swerdloff RS (1997) Early effects of vasectomy on testicular structure and on germ cell and macrophage apoptosis in the hamster Journal of Andrology 18 166-173

MacDougall MK, McCowin K, Derrick F, Jr, Glover L and Jacobson CS (1975) The effects of vasectomy on spermatogenesis in the dog, Canis familaris: a meiotic analysis Fertility and Sterility 26 786-790

McDonald SW (2000) Cellular responses to vasectomy International Review of Cytology 199 295-339

McDonald SW and Scothorne RJ (1988) A quantitative study of the effects of vasectomy on spermatogenesis in rats Journal of Anatomy 159 219-225

McLachlan RI (2000) The endocrine control of spermatogenesis Baillieres Best Practice and Research Clinical Endocrinology and Metabolism 14 345-362

Matthews GJ, McGee KE and Goldstein M (1997) Microsurgical reconstruction following failed vasectomy reversal Journal of Urology $157844-846$

Neaves WB (1978) The effect of vasectomy on the testes of inbred Lewis rats Journal of Reproduction and Fertility $\mathbf{5 4}$ 405-411

Orth JM, Higginbotham CA and Salisbury RL (1984) Hemicastration causes and testosterone prevents enhanced uptake of $\left[{ }^{3} \mathrm{H}\right]$ thymidine by Sertoli cells in testes of immature rats Biology of Reproduction $30263-270$

Owen E and Kapila H (1984) Vasectomy reversal. Review of 475 microsurgical vasovasostomies Medical Journal of Australia 140 398-400

Perera BM (1978) Changes in the structure and function of the testes and epididymides in vasectomized rams Fertility and Sterility 29 354-359

Putra DK and Blackshaw AW (1982) Morphometric studies of compensatory testicular hypertrophy in the rat after hemicastration Australian Journal of Biological Sciences 35 287-293

Ramaswamy S, Marshall GR, McNeilly AS and Plant TM (2000) Dynamics of the follicle-stimulating hormone (FSH)-inhibin B feedback loop and its role in regulating spermatogenesis in the adult male rhesus monkey (Macaca mulatta) as revealed by unilateral orchidectomy Endocrinology $14118-27$

Schanbacher BD, Fletcher PW and Reichert LE, Jr (1987) Testicular compensatory hypertrophy in the hemicastrated calf: effects of exogenous estradiol Biology of Reproduction 36 1142-1148

Shiraishi K, Naito K and Yoshida K (2001) Vasectomy impairs spermatogenesis through germ cell apoptosis mediated by the p53-Bax pathway in rats Journal of Urology 166 1565-1571 
Silber SJ (1979) Epididymal extravasation following vasectomy as a cause for failure of vasectomy reversal Fertility and Sterility 31 309-315

Silber SJ (1989) Pregnancy after vasovasostomy for vasectomy reversal: a study of factors affecting long-term return of fertility in 282 patients followed for 10 years Human Reproduction 4 318-322

Simorangkir DR, de Kretser DM and Wreford NG (1995) Increased numbers of Sertoli and germ cells in adult rat testes induced by synergistic action of transient neonatal hypothyroidism and neonatal hemicastration Journal of Reproduction and Fertility 104 207-213

Singh SK and Chakravarty S (2000) Histologic changes in the mouse testis after bilateral vasectomy Asian Joural of Andrology 2115-120

Singh SK and Dominic CJ (1981) Effect of vasectomy on the testis and accessory sex glands of the musk shrew Suncus murinus L Endokrinologie 77 137-146

Tung KS and Alexander NJ (1980) Monocytic orchitis and aspermatogenesis in normal and vasectomized rhesus macaques (Macaca mulatta) American Journal of Pathology 101 17-30

Ultee-van Gessel AM, Leemborg FG, de Jong FH and van der Molen HJ (1985) Influence of neonatal hemicastration on in-vitro secretion of inhibin, gonadotrophins and testicular steroids in male rats Journal of Endocrinology 106 259-265

Urena F and Malavasi J (1980) Ultrastructural study of the vasectomized hamster testis (Mesocricetus auratus) Revista de Biologia Tropical (Spain) 28 41-59

Urry RL, Dougherty KA and Cockett AT (1976) Vasectomy and vasovasostomy. I. Timing of histologic changes in immature and mature dog testis after vasectomy Fertility and Sterility 27 937-944

van Alphen MM, van de Kant HJ and de Rooij DG (1988) Folliclestimulating hormone stimulates spermatogenesis in the adult monkey Endocrinology 123 1449-1455

Waites GM, Wenstrom JC, Crabo BG and Hamilton DW (1983) Rapid compensatory hypertrophy of the lamb testis after neonatal hemiorchidectomy: endocrine and light microscopical morphometric analyses Endocrinology 112 2159-2167

Walton JS, Evins JD, Hillard MA and Waites GM (1980) Follicle-stimulating hormone release in hemicastrated prepubertal rams and its relationship to testicular development Journal of Endocrinology 84 141-152

Wang ZS, Zhao XJ, Lin H, Wang TL and Zhao JB (1992) Probing the pathogenesis of epididymal stasis and spermatic granuloma in epididymides after vasectomy Journal of Norman Bethune University of Medical Sciences (China) 18 30-33

Wang ZS, Zhao XJ, Li Y, Zhao D, Zhao LY and Wang QY (1994) The influence of vasectomy and vasovasostomy on testicular ATPases, CAMP, ABP and androgen receptor in rabbits Contraception 50 491-500

Wang ZX, Wreford NG and de Kretser DM (1989) Determination of Sertoli cell numbers in the developing rat testis by stereological methods International Journal of Andrology 12 58-64

Weiske WH (2001) Vasectomy Andrologia 33 125-134

Wen XH and Yang ZW (2000) Quantitative (stereological) study on the spermatozoal storage capacity of epididymis in rats and monkeys Asian Journal of Andrology 2 73-77
Wen XH, Wang XH, Tong JS, Yang ZW and Zhang GY (2000) Reversible effect of testosterone undecanoate injection on spermatogenesis in rats Asian Journal of Andrology 2 207-211

Whyte J, Sarrat R, Ortiz PP, Mazo R, Whyte A, Torres A and Cisneros A (1998) A morphological and morphometric study of the testicle in the rat vasectomized by electrocautery techniques Archivos Espanoles de Urologia (Spain) 51 849-855

Whyte J, Sarrat R, Cisneros Al, Whyte A, Mazo R, Torres A and Lazaro (2000) The vasectomized testis International Surgery 85 167-174

Wreford NG (1995) Theory and practice of stereological techniques applied to the estimation of cell number and nuclear volume in the testis Microscopy Research and Technique 32 423-436

Yamamoto M, Hibi H, Yokoi K, Mishima A and Katsuno S (1997) Surgical outcome of microscopic vasectomy reversal: an analysis of 30 cases Nagoya Journal of Medical Sciences 60 37-42

Yang ZW, Wreford NG and de Kretser DM (1990) A quantitative study of spermatogenesis in the developing rat testis Biology of Reproduction 43 629-635

Zhang RD, Wen XH, Kong LS, Deng XZ, Peng B, Huang AP, Wan Y and Yang ZW (2002) A quantitative (stereological) study of the effects of experimental unilateral cryptorchidism and subsequent orchiopexy on spermatogenesis in adult rabbit testis Reproduction 124 95-105

Zhao XJ, Wang ZS, Wang TL, Liu FX, Lu WW, Lin H, Wang P, Zheng ZC, Chen FC and Pan SQ (1987) Levels of plasma testosterone and quantitative histological observation of the testes in vasectomized rabbits Journal of Norman Bethune University of Medical Sciences (China) 13 312-314

Zhengwei Y, McLachlan RI, Bremner WJ and Wreford NG (1997) Quantitative (stereological) study of the normal spermatogenesis in the adult monkey (Macaca fascicularis) Journal of Andrology 18 681-687

Zhengwei Y, Wreford NG, Schlatt S, Weinbauer GF, Nieschlag E and McLachlan RI (1998a) Acute and specific impairment of spermatogonial development by GnRH antagonist-induced gonadotrophin withdrawal in the adult macaque (Macaca fascicularis) Journal of Reproduction and Fertility 112 139-147

Zhengwei Y, Wreford NG, Royce P, de Kretser DM and McLachlan RI (1998b) Stereological evaluation of human spermatogenesis after suppression by testosterone treatment: heterogeneous pattern of spermatogenic impairment Journal of Clinical Endocrinology and Metabolism 83 1284-1291

Zhengwei Y, Wreford NG, Bremner WJ, Matsumoto AM, Anawalt BA and McLachlan RI (1998c) Immature spermatids are not prevalent in semen from men who are receiving androgen-based contraceptive regimens Fertility and Sterility 69 89-95

Received 10 May 2002.

First decision 16 July 2002.

Revised manuscript received 18 July 2002.

Accepted 19 August 2002. 